\title{
12. China's price liberalisation and market reform: A historical perspective
}

\section{Zhang Jun}

China's old planned economy had many defects. The spontaneous partial changes in land contracting to households in rural areas in the early years of reform were fragmented and unsystematic, but they did not create the conditions for the meltdown of the planned economic system. Economic reform was put on the national agenda in 1984, when the third plenary session of the twelfth Central Committee of the Communist Party (CCCP) passed its 'Decision on the Reform of the Economic Structure'. This decision set the goal of establishing a 'socialist commodity economy' - an audacious innovation at the time. After that, China's economic strategy lifted its focus from the urban economy to comprehensive reform. This initial step towards market reform and deregulation in China was followed, 10 years later, at the third plenary session of the fourteenth CCCP, by enunciation of the goal to create a market economy with Chinese characteristics.

To establish a 'commodity' and then a market economy, China had to liberalise the planning mechanism for fixing prices, correct price distortions in outputs and inputs and 'get prices right'. The shift in the focus of reform from agriculture to the urban economy made the last goal more complicated. At that time, food and basic consumer products were rationed in cities. State-owned enterprises (SOEs) formed a significant part of the economy, controlling prices for the means of production. Even an adjustment in 1 cent for a box of matches would have to be discussed and approved by the State Council, and price changes involved many sectoral vested interests.

The key issue was finding the optimal way to implement price reform. Should it be letting go of price control in a single step or a gradual adjustment of planned prices to eliminate supply shortages? Was China in a position to ease price control in one go? Was it possible to realise the equilibrium price by gradually adjusting prices? How great would be the shock on the economy and society? Would price reform result in hyperinflation and consequently suffocate reform? These became hard issues in 1984 and beyond-not only for the leaders of reform, who were uncertain of which process to take, but also for Chinese economists.

By 1984, China already allowed the coexistence of two pricing systems for some agricultural products and several means of production. After 1984, Chinese economists started a focused discussion on the transition to price reform and a 'dual-track system'. A symposium in September 1984 was particularly important. 


\section{Moganshan symposium}

The First Symposium of Young and Middle-Aged Economists was held from 3 to 10 September 1984 on Moganshan Mountain in Zhejiang province. The organisers called for papers early in March and received ardent responses from young economists from universities and research institutes and from the young and middle-aged in government departments.

More than 1,300 papers were received, of which 120 were formally accepted. The symposium was sponsored by the relevant central government departments and supported by local government. The secretary of Zhejiang's provincial party committee, the governor and other leaders delivered speeches, and seven task forces discussed papers, which were subsequently published.

Many participants in the Moganshan symposium were well nurtured in economic theories and sharp in expressing novel ideas. The discipline of the young participants earned the respect of their older comrades.

The symposium discussed eight topics:

1. strategies of price reform

2. self-financing for industrial enterprises

3. multipurpose issues concerning key cities

4. opening up to the outside world in 14 coastal cities

5. problems with financial system reform

6. the development and management of the stock-holding economy

7. changes in rural industrial structure

8. the current economic functions of the government.

The most fruitful theoretical and ideological discussion was on the strategic issues of price reform.

The symposium's first conclusion was that prices of industrial mining products should be raised. The second was to adjust the prices of and excessive subsidies for agricultural products. Two competing approaches were put forward on industrial price reform: combining adjustment with deregulation, while focusing on adjustment, and combining adjustment with deregulation and adjustment after deregulation. The supporters of these ideas were labelled the 'adjustment group' and the 'deregulation group'. A third approach gained support at the end of the meeting: dual-track pricing of the means of production, unifying the two prices by gradually reducing centrally planned prices and gradually increasing the scope of market regulation. Hua Sheng wrote a summary of the symposium entitled 'To smoothly implement price reform via an intended dual-track system' (see Huang 2005). 
In 2005, Hua published an article titled 'The beginning and the end of the dual-track system' about the discussion of the 'dual-track system' at the Moganshan symposium:

The controversy existed initially between people for adjustment and those for deregulation. At that time, the mainstream participants who favored adjustment, either major or minor, argued in detail the necessity and urgency of the price reform and the feasibility of the price adjustment plan. They also depicted the difficulties and risks of [a] one-step move towards a balanced market price. However, Zhang Weiying, a graduate student from China's Northwestern University and the representative of the deregulation school, advocated one-step or step-by-step deregulation of price control and the implementation of prices according to market supply and demand. The main argument against the deregulation school was that in the context of a planned economy, the one-step deregulation of price control was too unrealistic, and the market development also required a process of being nurtured. Since the market was not perfect, the equilibrium price of [the] market was difficult to realize, and such [a] price might not be optimized ... [A] group of postgraduates (Hua Sheng, He Jiacheng, Jiang Yue, Gao Liang and Zhang Shaojie) from the Chinese Academy of Social Sciences and Renmin University ... finally formed the idea of implementing the dual-track system with the combination of deregulation and adjustment; and entrusted me to participate in the listed debate and defense on behalf of all of us. (Hua 2005: 22-3)

The above has been verified by Gao Liang, who works for the National Development and Reform Commission in Beijing and who attended the Moganshan symposium as a postgraduate student of the Chinese Academy of Social Sciences (CASS). An interview with Gao was cited in Huang's (2005) article in the Economic Observer. Gao said the adjustment group could also have been labelled the 'price-calculating group'. At that time, the central government established a huge price model for computer analysis. Zhou Xiaochuan, Li Jiange, Lou Jiwei and other scholars from CASS and Tsinghua University also tested their models, hoping to estimate the equilibrium prices and deregulated prices in one go via the government's price adjustment. However, as price adjustment affected many vested interests, reform would encounter enormous resistance regardless of the approach. At the Moganshan symposium, a group of scholars represented by Tian Yuan, who had participated in policy research, focused on 'adjustment'. In contrast, the 'deregulation group'represented by Zhang Weiying, a postgraduate student of China's Northwestern University-advocated gradual, step-by-step price control to bring about prices determined by market supply and demand (see Huang 2005).

The adjustment and deregulation groups actively published articles elucidating their views (representative articles include Lou and Zhou 1984; Guo 1985; Zhang 1985). The third group's suggestion of a dual-track transition with a combination of deregulation and adjustment immediately attracted the attention of State Council leaders. The CCCP's Decision on the Reform of the Economic System (October 1984), 
which was passed shortly after the Moganshan symposium, emphasised that reform of the price system would be the key to the success or failure of economic reform. In March 1985, the State Council officially abolished price control of above-quota producer goods. This decision was considered formal acceptance of dual-track reform. Hua et al. (1985) elaborated on the formation of the idea of the dual-track price system.

In 1988, on the 10th anniversary of the beginning of China's economic reform, Hua et al. (1988) published a long essay, referring to the Moganshan symposium and the process of formation of the idea of the dual-track price system. Their paper was immediately criticised, however, and their claims questioned by Shi Xiaomin and Liu Jirui (1989), who pointed out that the idea of a dual-track price system in China developed before 1984, and had been in use since 1979 for the reform of prices for agricultural products and other commodities. As for dual-track pricing of the means of production, Shi and Liu (1989) held that such a practice was clearly recognised in the 'Ten Articles on Power Expansion' promulgated by the State Council in May 1984_four months before the Moganshan symposium.

Twenty-three years later, Hua Sheng's memory of the Moganshan symposium was still quite fresh. He recalled in an interview with the Southern Weekend:

At that time I was a representative of the price group and reported to $\mathrm{Mr}$ Zhang Jinfu, then General Secretary of the Leading Group of the CPC Central Financial and Economic Committee. I was particularly impressed by this event. Shortly after the Moganshan symposium, the Third Plenary Session of the 12th CPC Central Committee was held, and, as Deng Xiaoping said, this meeting rendered something new that had never been mentioned by the forefathers of CPC. ${ }^{1}$ During that plenary session, the CPC Central Committee made a decision on the reform of the economic structure ... [This] was the heyday of reform, when we were often invited to attend the meetings of the State Council, and to organize reform pilots around the country. (Southern Weekend 2007: D27)

1 Deng Xiaoping's comment on the CCCP's decision on economic system reform comes from his speech to the third plenary session of the Central Advisory Commission on 22 October 1984. The original reads: 'I said a few words when the Central Committee passed the decision the day before yesterday. I said that my impression was that a first draft of political economy has been written and that this is the political economy which has combined the basic principles of Marxism with the practices of Chinese socialism. I have this comment ... This economic reform document is good, in the sense that has explained what is socialism, some sayings that have not [been] spoken by our CPC forefathers, some new words. I suppose that we have made it clear. In the past it was impossible for us to have composed such a document, and it is impossible to write such a document without a few years of practice.' See Deng (1993: 83-91). 


\section{The evolution of dual-track pricing}

After 1984, the central government adopted dual-track pricing as the transition strategy for market reform, but would this eventually lead to a market-clearing system? In my book Economics of Dual-Track System (Zhang 1997), I pointed out that the dual-track pricing of some products before 1984 was related to the partial reform of incentive policies in the system of product distribution and increased autonomy for producers (decentralisation). After 1984, the dual-track pricing system was adopted as a planned strategy for transition to promote micro-reforms and the establishment of a market system.

The Great Leap Forward in 1957 and the Cultural Revolution in 1966 had greatly weakened the centralisation of the Chinese economy, causing deviation from the model of the former Soviet Union. In the Soviet Union, SOEswerevertically integrated across production, supply and marketing by the specialised departments (Chinese planning officials called these 'lines') of the central government. Administrative decentralisation made all levels of local government (commonly known as 'blocks') in China-from the provinces (cities) to the lower-level counties-responsible for the management of some SOEs. Qian and Xu (1993) compared the organisational structure of China's planned management system with a multidepartmental corporate governance structure- that is, a multidivisional-form company.

This combination of lines and blocks that evolved through administrative decentralisation affected economic decentralisation and partial marketisation reforms after 1978. However, as this was simply an administrative decentralisation between central and local governments and did not involve the delegation of power to the firm level, no production or sales could be transacted above the planned quotas, although physical barter or swaps often occurred among SOEs affiliated with different planning administrators. ${ }^{2}$

One of the effects of the delegation to local government of power over the product allocation system was to enhance their planning allocation powers (Huang 1987). The number of products under central and departmental administration fell far short of that in the Soviet system (see Table 12.1). The share of planned products allocated by local governments, however, was increasing, including even some firstand second-class materials previously under central or departmental administration; in addition, products of the 'five small industries' (farm machinery, iron and steel, coal, fertilisers and cement), developed during the Cultural Revolution, came under local government administration. Table 12.1 shows that, in 1965, the share of coal allocated by the central government rose to 75 per cent, with the other

2 The work of Pan Zhenming and Luo Shouchu in 1988 analyses the material exchange between enterprises under the planned economy (Pan and Luo 1988). For the differences between administrative decentralisation and economic decentralisation, see Liu (1988). 
25 per cent allocated by local governments. In 1978, the local government share was 46 per cent. It was a similar story for cement: the local government share increased from 29 per cent in 1965 to 64 per cent in 1978, and to 70 per cent in 1979. The local government share of iron and steel soared to 42 per cent in 1979an increase of 37 percentage points from 1965.

Table 12.1 Share of products under planned allocation by local government (per cent)

\begin{tabular}{|l|r|r|r|}
\hline Product & 1965 & 1978 & 1979 \\
\hline Coal & 25 & 46 & 46 \\
\hline Iron and steel & 5 & 20 & 42 \\
\hline Timber & 37 & 19 & 18 \\
\hline Cement & 29 & 64 & 70 \\
\hline Lathe & n.a. & 65 & n.a. \\
\hline Automobile & n.a. & 25 & n.a. \\
\hline Nonferrous metals & n.a. & n.a. & 36 \\
\hline
\end{tabular}

n.a. = not available.

Sources: Huang (1987); Granick (1990); Pan and Luo (1988).

Real economic decentralisation-that is, delegating decision-making power to producers-began in 1979. In July 1979, the State Council promulgated its Regulations on Enlarging the Autonomy of Business Administration, and first proposed that manufacturing enterprises should enjoy the right of marketing their own products. This was an important starting point for expanding the autonomy of SOEs and a crucial step in the reform of the planned allocation system. These regulations allowed producers to enjoy limited but important freedom of decisionmaking power over 'above-quota' output (Zhang 1997). According to these regulations, the products enterprises could sell themselves were limited to output above the production quota, products made from raw materials mainly obtained by the enterprises themselves, trial production of new products and old stock that the commercial and material sectors did not plan to purchase.

Chen and Qiao (1994) revealed that, even though there were strict limits on production beyond quotas, these expanded rapidly and, by 1984, covered virtually all the means of production under the centrally planned distribution system. The share of products sold by enterprises continued to increase.

In 1981, oil field operators were permitted to autonomously export crude oil above the base figure, at international market prices. In 1983, the state allowed the export of crude oil to substitute for imports refined with products sold on domestic markets at international prices. This generated dual prices for refined oil. To encourage increased coal production, in 1983, the government chartered a price 
increase of 25-50 per cent for above-quota production in 22 stated-owned mining enterprises (SOMEs), also known as kuangwuju. In 1984, the updated charter planned to include up to 37 SOMEs in the initial stage of the dual-track pricing system by the end of the twentieth century (Zhang 1992). The Decision on Further Expanding the Autonomy of State-Owned Enterprises in May 1984 increased the decentralisation of enterprises based on the State Council's Provisions for Business Management Autonomy Expansion, promulgated in July 1979.

The 1984 decision allowed all above-quota industrial production materials sold by the enterprises themselves to be priced within \pm 20 per cent of the state-determined price. In January 1985, instructions from the State Council, the National Price Bureau and the National Materials Administration removed the original price limit of 20 per cent above the state-determined price and allowed enterprises to sell abovequota products at market prices. At the same time, SOEs were entitled to receive the planned transfer of supplies before 1983, while the quotas for allocated means of production would still be supplied at the transfer price based on the 1983 transfer quota. Output in excess of this base could be purchased at market prices. It could be said that, by this time, in the industrial sector, the dual-track pricing system for the means of production had been legalised.

From February to November 1985, the China Economic System Reform Institute and the Beijing Institute of Young Economists conducted a survey on the dual-track pricing practices of 429 state-owned industrial enterprises. In 1984, the ratio of self-produced production to total sales of these enterprises was 30.1 per cent. From January to June 1985 , the ratio had risen to 43.8 per cent. ${ }^{3}$

A research report by Diao Xinshen, based on this survey, offers a good analysis of how dual-track pricing affected the production decisions and behaviour of SOEs. Diao (1986: 47-8) wrote:

The dual-track system implies that there are, at the same time, two kinds of prices for the outputs and inputs of an enterprise: the official price set according to the state administrative regulations and the floating market price formed by the market forces or determined by both parties of the transaction. The products produced and materials supplied as planned or under the quotas will be transferred, bought and sold, and allocated according to the official prices; for those above the quotas, they will be sold or bought at the market price ... the market price, in fact, has played a decisive role for output and input of an enterprise at the margin. And via this marginal function, signals and impact have been formed to adjust the short-term supply and demand.

3 The product of this survey is a book titled Reform: The challenges and options we face (Diao 1986). 
According to the survey by the China Institute of Economic Reform (Diao 1986), from 1982 to 1984 , China saw an increase of 105.1 million tonnes in coal production, 55.9 million tonnes of which came from rural and township-owned mines (53.2 per cent), 22.6 million tonnes from local government-owned mines (21.5 per cent) and 26.6 million tonnes from central government-allocated mines (25.3 per cent) (see Table 12.2).

Table 12.2 Above-quota growth rate in coal production (per cent)

\begin{tabular}{|l|c|c|c|}
\hline \multirow{2}{*}{ Year } & \multicolumn{3}{|c|}{ Share of national coal production } \\
\cline { 2 - 4 } & $\begin{array}{c}\text { Centrally allocated } \\
\text { mines }\end{array}$ & $\begin{array}{c}\text { Local government- } \\
\text { owned mines }\end{array}$ & $\begin{array}{c}\text { Non-state-owned } \\
\text { mines }\end{array}$ \\
\hline 1978 & 55.3 & 29.1 & 15.6 \\
\hline 1979 & 56.3 & 26.7 & 17.0 \\
\hline 1980 & 55.5 & 26.2 & 18.3 \\
\hline 1981 & 53.9 & 25.7 & 20.4 \\
\hline 1982 & 52.5 & 25.6 & 21.9 \\
\hline 1983 & 50.8 & 25.4 & 23.8 \\
\hline 1984 & 48.3 & 25.0 & 26.2 \\
\hline Increase of 1984 over 1978 & 21.1 & 8.4 & 70.4 \\
\hline Increase of 1984 over 1982 & 7.7 & 13.3 & 38.3 \\
\hline
\end{tabular}

Sources: Data for 1982 and 1984 from Diao (1986); for other years, from Byrd (1987).

The surge in coal production by local government-owned and rural and townshipowned mines was mainly a result of new investment. In 1983, local governments raised RMB770 million chiefly by setting up or enlarging coalmines; more than 40,000 rural and township collectively owned mines were established within one year and the newly increased production capacity of the large collectively owned mines reached more than 10 million tonnes. Under the dual-track price system, profit-oriented enterprises tended to invest over the long term in products that would be regulated largely by the market; and, in turn, the share of market regulation expanded to gain above-quota growth.

\section{Debate over the dual-track price system and the comprehensive reform initiative}

In 1985, when the dual-track price system had been implemented in the industrial sector and for production materials, Chinese economists started a heated debate over the merits of this system. Guo Shuqing, Liu Jirui, Wu Jinglian, Lou Jiwei and Zhou Xiaochuan were the main economists opposed to dual-track pricing. They were also the main drafters and advocates of the 'comprehensive reform initiative'. 
A large part of the controversy over dual-track pricing in 1985 stemmed from associated macroeconomic imbalances and rent-seeking activities during the early years of transition to the new system. Gradual liberalisation of above-quota production and price controls allowed speculation in buying and selling outside quotas, and rent-seeking emerged among planning authorities. In 1984-85, high inflation was driven by explosive consumption spending. China's economists argued over what macromanagement policies should be implemented.

Economists who opposed the dual-track price system believed it increased inflationary pressure. In addition, the use of arbitrage opportunities by officials and enterprise executives seriously damaged the fair distribution of income. ${ }^{4}$

At the beginning of 1985, four CASS graduate students-Guo Shuqing, Lou Jiwei, Liu Jirui and Qiu Shufang_submitted a report to the State Council (Guo et al. 1985), in which they claimed the dual-track price system was fundamentally flawed and would lead to chaos and failure of market reform. Then, with the support of some leaders of the State Council, the students started work on the design of comprehensive reforms (Guo et al. 1986). In this research report, they pointed out the 'eight major demerits' of the dual-track price system. They advocated the speedy abolition of dual-track pricing and the adoption of a comprehensive reform strategy with a view to solving the current macroeconomic imbalance and the spread of corruption (Guo et al. 1986).

In 1986, Wu Jinglian, Zhou Xiaochuan, Guo Shuqing and Li Jiange, who were at that time working in the State Council Economic System Reform Design Office, undertook a series of studies on the overall progress of economic reform (see Wu et al. 1988). They openly opposed the dual-track price system, claiming it was the equivalent of allowing left-hand and right-hand driving on the same road, which would inevitably lead to crashes and chaos. They noted the coexistence of two prices encouraged buying and selling within and outside economic plans as well as rent-seeking activities, resulting in rampant corruption. Zhang Zhuoyuan (1992) has noted that some economists advocated that more than 80 per cent of dualtrack prices should be merged into the planned system as soon as possible. Only the limited, less important means of production, and those that supplied enough quantity to meet demand, would be traded in the market.

Criticism of the dual-track price system peaked at this time (see Zhang 1992).

In 1988, Wu Jinglian, an influential Chinese economist, held seminars in Beijing and Shanghai on the drawbacks of the dual-track system and compiled the results of discussions into a publication entitled Corruption: Exchange between power and money (Wu 1993).

4 Wu (2003: 66-70) also analysed the negative consequences of the dual-track price system and partial marketisation. 
The most heated controversy took place between 1988 and 1989 in the Economic Research Journal. Hua et al. (1988) held that the dual-track system was the basis of China's market reform. In early 1989, Shi and Liu responded, criticising and disproving the view of Hua et al.

Other economists still supported the idea of using dual-track pricing in the transition to market pricing. One of these was Liu Guoguang, a senior Chinese economist. In 1985, he argued that the dual-track price system could provide effective incentives for producers, reinforce awareness of the need for cost-cutting and ease shortages of certain supplies - all of which formed a viable path for China to follow in carrying out market-oriented reforms (Liu 1985).

From 2 to 7 September 1985, the International Symposium on Macroeconomic Management (known as the Bashan Ship Symposium) was hosted by the China Society for the Reform of the Economic System (later the National Economic Restructuring Commission), CASS and the World Bank on the Bashan, a cruise ship on the Yangtze River. Participating economists discussed the issue of price reform in China. In the proceedings of this symposium (Office of Development, Institute of Economic Research, Chinese Academy of Social Sciences 1987), Liu Guoguang and others mentioned the vigorous discussion on the importance of market transition via dual-track pricing, referring in particular to the positive attitude of Polish economist Professor Wlodzimierz Brus:

In China's dual-track system, the dual prices of products within and outside the plan are a typical embodiment of the dual planning system and the dual material distribution system. In the process of mode conversion, starting from the price reform with the combination of adjustment and deregulation, employing the intended changes of dual prices, and promoting the overall reform of the economic system, we can thus avoid a big shock that may be incurred by the reform. As Brus has stated, in a change from the rationing system to the commodity system, other socialist countries used to practice dual prices on consumer goods, but China has introduced dual prices into the means of production - this may be a positive creation: it serves as a bridge from the old system to the new system, allowing a smooth transition from direct control of the administration to indirect control through the market. (Office of Development, Institute of Economic Research, Chinese Academy of Social Sciences 1987: 10)

Should the reform of China's economic system proceed step by step or in a single move? Economists today talk about these two different strategic approaches as 'radical reform' and 'gradualist reform'. Chinese economists' discussion of these issues came 10 years before mainstream economists in the West began work on theoretical issues of reform.

The most dramatic change in the formation of China's economic reform strategy occurred in 1986. Economists were divided over strategies for and the sequence of price reforms: should reform of prices or reform of enterprise ownership come first? 
From the third plenary session of the eleventh CCCP in December 1978 to the third plenary session of the twelfth CCCP in October 1984, China's reform focused on the liberalisation of agricultural production. The CCCP did not develop an approach to the overall reform of the economic system. The breakthrough Decision on the Reform of the Economic Structure was passed at the third plenary session of the twelfth CCCP, clearly setting out the goal of establishing a socialist commodity economy, and shifting the focus of comprehensive reform from rural to urban areas.

The 1985 CCCP passed its 'Proposal for Enacting the Seventh Five-Year Plan (1986-1990)', which included establishing, over five or more years, a basic economic system coordinated by the three systems of enterprise autonomy, market allocation and macro control. During that time, China's macroeconomic imbalances-external payments and inflationary pressures - were large. Reform of the economic system against such a macroeconomic background became the most important issue.

With economists disagreeing about the focus and sequence of reforms, Professor Li Yining of Peking University famously asserted that 'if China's reform fails, it may fail in price reform; and if China's reforms succeeds, it must be the result of the success of ownership reform' (quoted in Wu 2003: 73). Li believed China's economy was in an unbalanced state, and would stay that way a long time. In an unbalanced economy, it was not practical to improve the economy through price reform; therefore, China should focus on reform of enterprise ownership. Only through this could distorted price relations be corrected.

Other economists — such as Guo Shuqing (then studying in CASS's Graduate School), Lou Jiwei, Liu Jirui, Qiu Shufang, Wu Jinglian, Zhou Xiaochuan, Guo Shuqing and Li Jiange (who later worked in the State Council Economic Structural Reform Office)_formed the idea of a comprehensive reform package. Their earlier work must have influenced Zhao Ziyang, then premier of the State Council.

Between January and March 1986, Zhao delivered speeches at the National Economic Work Conference, the CPC Central Financial and Economic Leading Group Meeting and State Council executive meetings. He said that, in 1987-88, major steps should be taken to speed up the establishment of an institutional environment conducive to micro-competition:

Specifically, the reform in the next year [1987] can be designed and studied from the following three aspects: the first is the price, the second is the tax, and the third is the finance. These three aspects of reform are interrelated ... The key is the reform of the price system, and other reforms are carried out around the center of the price reform. (Quoted in Wu 2003: 72) 
The steps identified in Premier Zhao's speech were quickly executed, followed by planning and design of reform programs. In his book Contemporary China's Economic Reform, Professor Wu Jinglian briefly reviewed this detail of his participation:

In order to carry out the proposed complementary reforms, the State Council established in April 1986 the Office of Economic Reform Program Design. Under the direct leadership of the State Council and the CPC Central Financial Leading Group, the office formulated the plan of complementary reforms focusing on price, taxation, finance and trade, of which the price reform was to start in 1987 in the means of production. The reform approach was similar to the one introduced by Ota Sik as early as 1981 to his Chinese counterparts of the practice of reform in Czechoslovakia in the mid-1960s: 'Adjust first, then deregulate.' First, comprehensive adjustments of prices were made ... and then controls on prices were totally lifted in one or two years, so as to fully achieve the unification of all prices. In terms of finance and taxation, the major steps were to convert the revenue-sharing system into the tax-sharing system and to introduce the value-added tax (VAT) and so on. (Wu 2003: 72-3)

Wu (2003) wrote of a dramatic and sudden change. An executive meeting of the State Council originally approved the design of the comprehensive reform package in August 1986; Deng Xiaoping himself supported this idea and rated it highly. However, in October, the leadership of the State Council suddenly changed its mind and decided to focus on reforming the ownership of SOEs, putting aside the proposed comprehensive and complementary reforms on prices, taxes and finance. In 1987 and 1988, with Li Peng now premier of the State Council (and Zhao Ziyang general secretary of the CCP), it decided to implement the contract system in SOEs. In other words, Li's thinking prevailed, replacing the focus on comprehensive reform.

In May 1988, when the State Council planned to carry out reform of prices and wages, the leadership finally rejected the idea of 'governance first, and then breakthrough' proposed by Wu Jinglian, Liu Guoguang and others, and instead adopted the view of Li Yining. This explains the following comment by Wu Jinglian published on the (now closed) China Academic Forum website:

For several key moments, the policy proposals that later proved to be correct have been put forward to the center, and the basic idea of the economic reform and development strategy that he [Li] proposed, as well as many other policy proposals (such as the anti-inflation suggestion of 1984-1988) have now been proved correct by practice, although successive government leaders have often overlooked his views.

We do not have sufficient information to understand why the leaders of the State Council changed their minds in October 1986; however, there was a direct connection with the current macroeconomic situation. After the State Council adopted a policy of economic tightening during the inflation of 1984-85 and the People's Bank of China adopted a stringent monetary policy in the second half of 1985-raising 
interest rates twice in a row and tightening credit control-the economic growth rate declined sharply, to zero, in February 1986. In this sensitive period of economic downturn, it was very likely the State Council would consider easing monetary policy to stimulate production. The short-term effect of a comprehensive reform package centred on price reform was likely to be economic tightening. However, the focus was on reform of the enterprise and financial contract systems, decentralising power and helping to improve supply and restore prosperity.

\section{The dual-track price system: A miracle or a myth?}

It is now generally accepted that China's gradualist transition to a market economy has been relatively successful and has accelerated economic growth over the past 40 years. This chapter has shown that assessments of the dual-track price system in the early stage of China's market reform are mixed and controversial. There are different views on whether the time frame for the hybrid system of dual-track pricing to begin functioning was too short or too long. Either way, the hybrid system of a planned and market economy can be witnessed almost everywhere in post-reform China.

The idea of a dual-track price system and the coexistence of planning and the market in the Chinese economy have stirred great interest among mainstream economists.

William Byrd, an economist for the World Bank, made the dual-track price system the topic of his doctoral dissertation in economics. Papers based on the dissertation were published in the Journal of Comparative Economics (Byrd 1987, 1989). In his 1989 paper, Byrd defined a simple general equilibrium model in the hope of verifying the existence of equilibrium under the dual-track price system. If equilibrium exists, does this equilibrium satisfy the conditions of Pareto optimality?

His model was simple. Some of the key assumptions were: the existence of planned pricing and planned quotas, free markets not covered by the plan, planned targets lower than the productive capacity of the enterprise (so-called leftover plans) and SOEs pursuing profit maximisation.

As long as some strict conditions are realised, the efficiency of the coexisting planned and market tracks is actually equivalent to that of the market track alone. The existence of a planned track only changes the distribution of income, not the level of efficiency. This is much like the case when an economic agent within a typical market system is faced with a fixed amount of tax or subsidy. 
Lau et al. $(1997,2000)$ later offered a simpler theoretical treatment of the dualtrack price system, which they treat as a mechanism for the allocation of goods, demonstrating its allocative and Pareto efficiency in the first case:

If the plan quantity is less than the fully liberalized market equilibrium quantity, then, independently of the initial conditions concerning the plan price and the degree of efficiency of rationed demand and planned supply, (1) the dual-track approach with either limited or full liberalization of the market track is Pareto-improving, and (2) the dual-track approach with full liberalization of the market track achieves efficiency. (Lau et al. 2000: 128)

They also consider the second case where the planned quantity is greater than the equilibrium quantity of a perfect market. This case applies to the overproduction of goods such as tanks and other low-quality unwanted goods or to the overemployment of labour. Their discussion shows that the results of Case II are quite similar to those of Case I.

Under partially liberalised market conditions, surplus demand and surplus supply could be balanced via the market track. Due to the large quantity of planned allocations (assignments), however, the total equilibrium quantity would be greater than the efficient equilibrium quantity, which is not efficient, although it is Paretoimproving.

Under fully liberalised market conditions, however, Lau et al. (2000) find that allocative efficiency can only be achieved when the rights and obligations in the plan can be exchanged on the market. They reach a different conclusion:

If the plan quantity is greater than the fully liberalized market equilibrium quantity, then independently of the initial conditions concerning the plan prices and the degree of efficiency of rationed demand and planned supply, (1) the dual-track approach with limited or full liberalization is always Pareto-improving and (2) the dual-track approach with full liberalization achieves efficiency if the rights and obligations under the plan are enforced in terms of the rents. (Lau et al. 2000: 132)

This result reminds us of the famous 'Coase theorem'. 5 Because of Pareto improvement, a dual-track price system transitioning to a market price system creates no losers, and improves the lot of some people.

The above theoretical propositions are naturally conditional. To ensure the Paretoimproving nature of a dual-track price system, one needs to assume that the rights and obligations of the plan are fully guaranteed and fulfilled. For example, if the planned obligations are not implemented or there are violating behaviours between the planned track and the market, the dual-track system as a mechanism of transition

5 I have previously analysed and discussed the Coase theorem and its application in China's economic restructuring strategy (see Zhang 1997: 72-8). 
will be greatly endangered. Under the dual-track system, the government should ensure the effective implementation of the rights and obligations in the plan, but this is not a given in many transitioning economies.

Murphy et al. (1992) find the reason the partial marketisation of the former Soviet Union (1985-91) was unsuccessful and did not lead to growth in production was probably due to the failure to achieve the planned distribution of some important means of production in certain SOEs. As a result, producers of these important means of production were free to choose to whom they would sell, while private firms were also free to buy their means of production at market prices, but the price controls were maintained by the state sector. Owing to the constraints of the existing planning system and price controls, SOEs were unable to compete with private enterprises in obtaining the means of production, and their production stalled. Large quantities of important means of production flew from SOEs to the weaker private sector.

Whether the fulfilment of the planned obligations of the original producers can be guaranteed is crucial to the smooth transition of production in the early stage of economic reform:

China has pursued partial reforms of the sort described here, except that the central government maintained extremely strict enforcement of state quotas and allowed firms to sell only the units above the state quotas to private buyers. As a result, the government managed to contain the supply diversion problem. The Soviet government, in contrast, while nominally retaining delivery quotas for state enterprises, substantially relaxed plan enforcement. (Murphy et al. 1992: 899)

Therefore, for a Pareto improvement of the dual-track price system, it is imperative the reformers are capable of guaranteeing the implementation of the planned obligations during the period of market reform. This precondition obviously depends on the political climate. It is clear that China is pushing forward partial reforms within the existing political and administrative system, which maintains the authority of the central government and makes use of the existing political and organisational resources. During the period of partial reforms in the former Soviet Union, however, the authority of the ruling party and the government was greatly weakened, and the government was unable to maintain its original planned track. This is a significant difference. China has always been able to make full strategic use of its political and organisational resources for reform, which explains why its partial and gradual reforms have evolved smoothly.

All in all, when the dual-track price system was put forward as a reform idea at the Moganshan symposium in 1984, China had already been experiencing both planned and market systems in industrial production. The dual-track price system continued through the entire 1980s and into the first half of the 1990s. It generally did not cause violent friction or turmoil, and output grew. How did China maintain 
a dual-track system for so many years? Economists have become obsessed with this question. Some have associated the dual-track system with the ideal model of market socialism put forward more than half a century ago by Oskar Lange and Fred Taylor.

In the 'Great Socialist Debate' of the 1930s, Lange and Taylor developed their own thinking about the combination of planning and the market. ${ }^{6}$ The model they conceived has a serious problem with incentives and cannot overcome the monopoly and bureaucratic problems of producers (SOEs). Australian economist Professor Clem Tisdell said of China's dual-track price system and the model of market socialism of Lange and Taylor:

There are a number of differences and similarities between socialist and market systems such as those proposed by Lange and Taylor and China's two-tiered price system. Both systems aim at balancing market supply and demand. But the Lange and Taylor system requires the use of state marketing authorities. The two-tiered system only involves state authorities in exchange in relation to the portion of production subject to an official quota, and some products in China are not subject to any production quotas at all, so that the whole of supply and demand is subject to direct exchange between sellers and buyers in markets. Therefore, the Chinese system may be less costly in terms of market transaction costs than the Lange and Taylor scheme. Furthermore, it does not require the state to hold buffer stocks or to use equalisation funds to effect marketing, even though it makes prices more risky or uncertain for sellers than Lange's or Taylor's scheme. (Tisdell 1993: 148)

\section{Conclusion}

Over the past four decades, market reform of China's economy has secured unprecedented achievements in economic growth and structural change. The starting point of this marketisation was to relax and reform the centralised planning system. The key issue was how to transform planned prices into market-determined prices so as to correct distortions and resource misallocation. In 1984, the Communist Party maintained that reform of the price system would be the key to the success or failure of reform of the entire economic system. At the same time, it held that price system reform should proceed with caution since it was closely related to the overall state of the national economy and millions of households. Based on its development of production and the availability of financial resources, China could formulate a comprehensive plan and a step-by-step implementation to ensure that people's real income gradually grows.

6 For an explanation of these ideas, see Lange (1981) and Taylor (1987). 
Unlike most transitioning economies, in China the stages of market-oriented reforms were carefully planned and gradually advanced. It is naive and risky to believe that the dismantling of planning control can automatically convert a planned economy into a market economy. In shifting from a planned to a market economy, China's reform leaders were very cautious and patient.

China's experience shows that one of the ways to carefully handle market reform is to employ an extensive process of trial and error: make full use of existing experience, use local pilot projects to determine the conditions that can be utilised and then, once the trials have rendered the expected results, shift the trials to a larger scale, making sure the entire process does not cause major shocks to the economy.

Before 1984, dual-track pricing already existed for some products, including agricultural produce and coal. After 1984, however, economists promoted the dualtrack price system as a transition strategy to facilitate market reforms.

As illustrated by the formation of the idea of price reform, reformers and economists have forged a good relationship in the process of making reform easier and minimising its social cost-a relationship that has been absent in other transitional economies. This practice continues in China.

\section{References}

Byrd, W. (1987), The impact of the two-tier plan/market system in Chinese industry, Journal of Comparative Economics 11(3): 295-308. doi.org/10.1016/ 0147-5967(87)90056-4.

Byrd, W. (1989), Plan and market in the Chinese economy: A simple general equilibrium model, Journal of Comparative Economics 13(2): 177-204. doi.org/ 10.1016/0147-5967(89)90001-2.

Chen, G. and Qiao, G. (1994), Formation and price reform of the product market, [in Chinese], in F. Gang, L. Yang and Z. Zhenhua (eds), Towards the Market: 1978-1993, Shanghai: Shanghai People’s Publishing House.

Deng, X. (1993), Selected Works of Deng Xiaoping. Volume III, [in Chinese], Beijing: People's Publishing House.

Diao, X. (1986), Price: The role of dual-track system and the direction of further reform, [in Chinese], in Survey Group of China Economic System Reform Institute (ed.), Reform: The challenges and options we face, Beijing: China Economic Publishing House. 
Granick, D. (1990), Chinese State Enterprises: A regional property rights analysis, Chicago: University of Chicago Press.

Guo, S. (1985), On the targeted models of China's price system reform, [in Chinese], Journal of Graduate School of Chinese Academy of Social Sciences (3): 30-7.

Guo, S., Lou, J. and Liu, J. (1986), On the overall planning of system reform, [in Chinese], Reference Materials of Economic Research (35).

Guo, S., Lou, J. and Qiu, S. (1985), Comprehensive reform requires overall planning: A problem concerning the destiny of China's reform, [in Chinese], Comparison of Economic and Social Institutions (1): 21-6.

Hua, S. (2005), The beginning and the end of dual-track system, [Chinese trans.], China's Reform 1: 22-5.

Hua, S., He, J., Jiang, Y., Gao, L. and Zhang, S. (1985), On the road of price reform with Chinese characteristics, [in Chinese], Economic Research Journal (2): 27-32.

Hua, S., Zhang, X. and Luo, X. (1988), China's ten-year reform: Review, reflection, and prospects (Review), [in Chinese], Economic Research Journal (2): 13-37.

Huang, C. (1987), The role of local governments in planning and markets, [in Chinese], Comparative Social and Economic Systems (1): 14-19.

Huang, P. (2005), Hua Sheng: Dual-track system, Economic Observer, 4 July.

Lange, O. (1981), The Theory of Socialist Economics, [Chinese trans.], Beijing: China Social Sciences Press.

Lau, L., Qian, Y. and Roland, G. (1997), Pareto-improving economic reforms through dual-track liberalization, Economic Letters 55(2): 285-92. doi.org/ 10.1016/S0165-1765(97)00062-1.

Lau, L., Qian, Y. and Roland, G. (2000), Reform without losers: An interpretation of China's dual-track approach to transition, Journal of Political Economy, 108(1): 120-43. doi.org/10.1086/262113.

Liu, G. (1985), Economic system reform and macroeconomic management: Reviews on 'Macroeconomic Management International Symposium', Economic Research (12): 3-19.

Liu, J. (1988), On administrative decentralization and economic decentralization, [in Chinese], Comparison of Economic and Social Institutions (3): 8-14.

Lou, J. and Zhou, X. (1984), On the direction of China's price system reform and related models and methods, [in Chinese], Economic Research Journal (10): 13-20. 
Murphy, K., Shleifer, A. and Vishny, R. (1992), The transition to a market economy: Pitfalls of partial reform, The Quarterly Journal of Economics 107(3): 887-906. doi.org/10.2307/2118367.

Office of Development, Institute of Economic Research, Chinese Academy of Social Sciences (1987), Proceedings of China's Economic Reform: International Symposium on Macroeconomic Management on Bashan Ship, [in Chinese], Beijing: China Economic Publishing House.

Pan, Z. and Luo, S. (1988), Theory of Socialist Microeconomic Equilibrium, [in Chinese], Shanghai: Shanghai Joint Publishing Corporation.

Qian, Y. and Xu, C. (1993), Why China's economic reforms differ: The M-form hierarchy and entry/expansion of the non-state sector, Economics of Transition 1(2): 135-70. doi.org/10.1111/j.1468-0351.1993.tb00077.x.

Shi, X. and Liu, J. (1989), Economists must first respect history and facts: Comments on 'Ten years of China's reform: Review, reflection, and prospects (Review)' by Hua Sheng et al., [in Chinese], Economic Research Journal (2): 12-34.

Southern Weekend (2007), Happiness is 'what the heart likes', [in Chinese], Southern Weekend, 17 May.

Taylor, F. (1987), The production guidance for socialist countries, [in Chinese], Comparison of Economic and Social Systems (3): 51-4.

Tisdell, C. (1993), Economic Development in the Context of China: Policy issues and analysis, London: Macmillan. doi.org/10.1057/9780230380189.

Wu, J. (ed.) (1993), Corruption: Exchange between power and money, [in Chinese], Beijing: China Economic Publishing House.

Wu, J. (2003), Contemporary China's Economic Reform, [in Chinese], Shanghai: Shanghai Far East Publishing House.

Wu, J., Zhou, X., Guo, S. and Li, J. (1988), Overall Design of China's Economic Reform, [in Chinese], Beijing: China Prospect Press.

Zhang, J. (1997), Economics of Dual-Track System: China's economic reform (19781992), [in Chinese], Shanghai: Shanghai Joint Publishing Corporation and Shanghai People's Publishing House.

Zhang, W. (1985), On the idea of focusing on 'deregulation' in the price reform, Reference Materials of Economic Research (6). 
Zhang, Z. (1992), Prospect of price reform in China in the 1990s, [in Chinese], in M. Xue, G. Liu, M. Wang, S. Sun, J. Wang, Z. Xiao, J. Tian, Y. Dai, T. Zhu, J. Li, J. Chen, H. Wang, L. Ji, S. Gao, J. Wang, S. Zhou, J. Wu, T. Mao, F. Dong, Z. Zhang, J. Chen, S. Zhou, Z. He, H. Zhao, S. Liu, C. Ji, L. Zhao, X. Zeng, X. Tian, S. Yang, Q. Zhu, S. Zhang, L. Di, C. Li, F. Huang and D. Yu, China's Economic Development and Reform Exploration in the 1990s, Beijing: Economic Science Press. 
This text is taken from China's 40 Years of Reform and Development: 1978-2018, edited by Ross Garnaut, Ligang Song and Cai Fang, published 2018 by ANU Press, The Australian National University, Canberra, Australia.

doi.org/10.22459/CYRD.07.2018.12 